\title{
水の流れの理屈を探る
}

—水力学・水理学専門委員会の活動から—

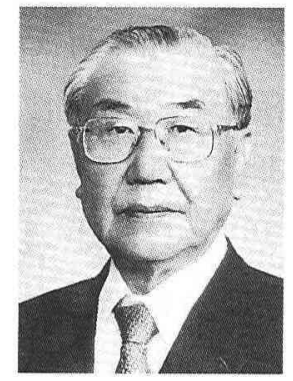

椹木 亨

\section{1. 研連から專門委員会への脱皮}

従来の第5部所属の水力学・水理学研連は第 5 部の研連の見直しに伴い、メカニクス・構造 研連の中の「水力学 ·水理学専門委員会」とし て再発足した。この変革にともない構成委員 も3名の減となったが、従来の研連の時と同様 の活動を継続している。

16期においては「水力学・水理学分野にお ける計算流体力学の現状と課題」を対外報告と してとりまとめた。17期に打いては、後述す るような公開シンポジュウムの開催を継続的 に行うこと以外に「水力学・水理学分野におけ る一般向け広報と社会的な評価の資料蒐集と その対外報告の取りまとめ」を活動計画の主眼 におくこととした。

すなわち、昔からいわれているように水は高 き所より低き所へ流れるということはわかって いるが、その理屈を何故研究しなければならな いのか、その結果をどのような所に応用されて いるのかは一般の人々は無関心である。しかし ながら、このような水の流机は一般生活のいた るところで重要な役目をもっている。この事実 を各学会はどのように広報しているかを調查 し、もし不十分であるならばどのようにすれば よいかを考えようとするのが前半の命題であ
る。

つぎにそれらの研究がどのような形で社会 的に役立っているかを自己評価し、同時に一 般の人々から評価を受けているかを明確にし ようとするのが後半の命題である。これらの 作業は各委員の所属している機械学会、土木 学会、農業土木学会、造船学会、混相流学会 別に調査し、どのようにまとめるかについて は現在検討中であるが、すでに市民をまきこ んだ行事の中で、水の流れを研究する必要性 をアッピールしている学会も少なくない。

\section{2. 公開シンポジュウムの開催について}

従来より本委員会が主催しているシンポジ ュウムは、混相流シンポジュウム、キャビテ ーションに関するシンポジュウム、「C.G.でみ る流れの世界」シンポジュウムなどがある。い ずれも多くの関連する学会があり、そのなか で専門の枠をこえて集まり十分な討議をして きた。

ここで1998年7月23日、24日にわたって東京 の工学院大学で行われた混相流シンポジュウ ム'98について紹介しておこう。混相流といっ ても一般の人々にはなにをさしているのかわ からないであろう。混相流とは気体と液体、 
気体と固体、液体と固体あるいは三者が混ざ りあったもので、たとえばボイラーに打ける 水循環は気液二相問題であり、粉体輸送は気 体と固体問題、浚渫土砂をパイプで輸送する のは液体と固体の問題である。したがって混 相流に関連する学会は34を数える。今回発表 された論文は106件にのぼり、それらは混相流 の物理、混相流の数值シュミレーション、計 測技術、ダイナミクス、界面現象、環境対策 技術などの各セッションにわかれて討議が行 われた。

特に第一日目 (23日)の $13 ： 30$ より1時間お こなわれた特別講演は東大名誉教授植田辰洋 先生により「気液よもやま話」と題して初期の 気液二相流研究の話をされ、それらに基づい て今後の研究課題について言及された。そし て気液二相流には未だ未解決の部分が多く残 されており、新たな流体力学の分野を締めく くっておられた。

本委員会はこのシンポジュウムに続くシンポ ジュウムとして平成11年4月23日24日の2日間、 東京の工学院大学で日本学術会議 50 周年記念 シンポジュウムとして、「C.G.で見る流れの世 界シンポジュウム」を計画している。このシ ンポジュウムは、平成 6 年 4 月に第 1 回を開催し
てより平成 8 年に第2回を開催し、今回が3回目 にあたる。いずれも前半1日半を一般講演の部 とし、後半半日を特別講演として市民の方々 に開放して流れの世界をコンピュータ・グラフ イクスで再現して、従来目に見る事のできな い流れの世界を知って頂こうとするもので、 1. 「研連から専門委員会への脱皮」で述べた流れ の研究の広報活動の一翼をになってもら打う と意図したものである。過去2回は一般の方々 に深い感銘を与えたが、今回も話題を変えて 一般の方々に参加頂こうと計画している。

この結果については後日報告する機会が与 えられると思うが、貯水池の水質変化、洪水 による河底の変化など環境面での問題、さら に水車内部の流れの変化、流れを粒子の集ま りと見なしてそれらをどのように工業化につ なげていくかなどをわかりやすくビデオを用 いて説明して頂く予定である。

これらの活動以外にも、本委員会は環境数 值体力学シンポジュウムにも後援しており活 発な活動を繰り広げている。

椹木 亨（さわらぎ とおる 1931年生）

日本学術会議第5部会員、社会・環境研究連絡委員会委員 長、水力学・水理学専門委員会委員長、計画工学専門委員 会委員、大阪産業大学教授、大阪大学名誉教授、工学博士 専門 : 海岸工学 